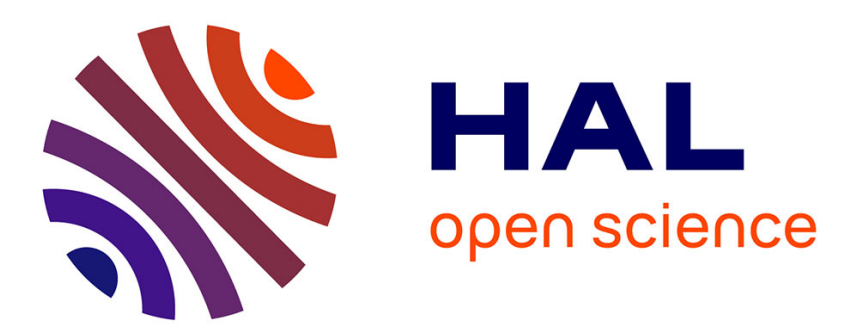

\title{
Synthesis of BaFe12O19 by Oxi-Coprecipitation from Hydrochloric Steel Pickling Liquors
}

\author{
R. Latorre, J. Dufour, J. García, E. Alcalá, C. Negro, F. López-Mateos
}

\section{To cite this version:}

R. Latorre, J. Dufour, J. García, E. Alcalá, C. Negro, et al.. Synthesis of BaFe12O19 by OxiCoprecipitation from Hydrochloric Steel Pickling Liquors. Journal de Physique IV Proceedings, 1997, 07 (C1), pp.C1-85-C1-86. 10.1051/jp4:1997123 . jpa-00254903

\section{HAL Id: jpa-00254903 https://hal.science/jpa-00254903}

Submitted on 1 Jan 1997

HAL is a multi-disciplinary open access archive for the deposit and dissemination of scientific research documents, whether they are published or not. The documents may come from teaching and research institutions in France or abroad, or from public or private research centers.
L'archive ouverte pluridisciplinaire HAL, est destinée au dépôt et à la diffusion de documents scientifiques de niveau recherche, publiés ou non, émanant des établissements d'enseignement et de recherche français ou étrangers, des laboratoires publics ou privés. 


\title{
Synthesis of $\mathrm{BaFe}_{12} \mathrm{O}_{19}$ by Oxi-Coprecipitation from Hydrochloric Steel Pickling Liquors
}

\author{
R. Latorre, J. Dufour, J. García, E.M. Alcalá*, C. Negro and F. López-Mateos \\ Dpto. Ingenieria Química, Facultad de Ciencias Químicas, Universidad Complutense de Madrid, Avda. \\ Complutense s/n, 28040 Madrid, Spain \\ * Dpto. Fisica de Materiales, Facultad de Ciencias Fisicas, Universidad Complutense de Madrid, Avda. \\ Complutense s/n, 28040 Madrid, Spain
}

\begin{abstract}
The steel pickling liquour is formed by $\mathrm{HCl}$, washing water and a high content of le(II). This liquor is mixed with a $\mathrm{Ba}(\mathrm{I})$ solution in a stoichiometric rate to produce a precursor powder to ohtain $\mathrm{BaF}_{32}, \mathrm{~F}_{14}$. In all cases we abiained a mixture of $\mathrm{BaFe} \mathrm{Fe}_{12} \mathrm{O}_{19}$ and $\alpha-\mathrm{Fe}_{2} \mathrm{O}_{3}$. The qualitative and quantitative analyses were made by XRD and the magnetic propertics were measured by VSM technique. We will report the relation between the oxi-coprecipitation process conditions and the magnctic properties and the role of $\mathrm{NaCl}$ during the calcination step. $\mathrm{NaCl}$ was formed from dissolution in the oxi-eoprecipitation process. NaCl originates structural defects in the powder so, the solid state reaction, during the calcination process, is improved. An excess of $\mathrm{NaCl}$ didn't increase the magnetic properties and promoted by-products formation, so the $\mathrm{Fe} / \mathrm{Ba}$ rate is stoichometric but calcined products had low magnetic properties.
\end{abstract}

\section{INTRODUCTION.}

The steel pickling liquor is a steelmaking wastewater originated for cleaning surlace in the last step of steel processing using $\mathrm{HCl}$ as pickling agent. It is formed by $\mathrm{HCl}$, washing water and a high content of $\mathrm{Fe}(\mathrm{Il}) \mathrm{HCl}$ is previously recovered and recycled to the pickling bath and the effluent, without free acid, is useful to synthesize $\mathrm{BaFe}_{12} \mathrm{O}_{10}$. It is necessary to oxidize Fe(II) to $\mathrm{Fe}$ (III) by air as oxidizer agent for precipitation process. This process, called oxi-coprecipitation process, is one of the wet methods for preparing a precursor powder to synthesize by calcination $\mathrm{BaFe}_{12} \mathrm{O}_{19}$. In a furs step $\mathrm{Fe}$ (II) is oxidized to Fe(III) and, during precipitation of Fe(III) process, a coprecipitation of $\mathrm{Ba}(\mathrm{Il})$ is produced. In this way, the powder is homogeneous in an atomic scale and, due to the $\mathrm{pH}$ where the precipitation is made, the powder is highly reactive, very amorphous and $\mathrm{NaCl}$ is present in the powder. $\mathrm{NaCl}$ reduces the activation energy of solid state reaction.

\section{EXPERIMENTAL PROCEDURE.}

The oxi-coprecipitation was carried out using a glass made reactor closed with a lid that has five openings for inserting the diffusor, stirer, themometer, condenser and the system for adding the basic agent. The body of the reactor has a side opening for inserting the $\mathrm{pH}$ electrode. We prepared in the laboratory a synthetic hydrochloric liquor with $50 \mathrm{~g} / \mathrm{l}$ ol $\mathrm{Fe}$ (II). This liquor was mixed with a dissolution of $\mathrm{BaCl}_{2}$ in order to obtain a rate of Fe/Ba stoichonetric 10 produce the precursor powder. The oxiprecipitation was made, controlling temperature, at $20 ; 45$ and $70^{\circ} \mathrm{C}$ and $\mathrm{pH}$ at $10 ; 11 ; 12 ; 13$, using $5 \mathrm{l} / \mathrm{min}$ of air with a porous plate diflusor as Fe(II) oxidizer agent. Like basic agent we used $\mathrm{Na}_{2} \mathrm{CO}_{3}$ saturated dissolution of $\mathrm{NaO} / \mathrm{I} 10 \mathrm{M}$. The ruaction was finished when the $\mathrm{pH}$ was constant during, at least, 15 minutes. The precipitate was separated from the solution by liltration without washing and dry in an oven during, at least, 48 hours. The rate Fe/Ba in the precipitated was measured hy atrimic absontion spectroscopy. The crystallinity and the qualitative analysis of crystalline phases were made by $\mathrm{X}$-ray diftiaction.

The powder was calcined at $900^{\circ} \mathrm{C}$ during 3 hours to obtain $\mathrm{BaF} \mathrm{e}_{12}()_{10}$. The qualitalive and quantitative analyses were made by XRD and the magnetic properties were measured by VSM teclinigue.

\section{RESULTS.}

From the solution obtained after filtration we can determine the Ba percentage coprecipitated in the process. These results are shown in table I. In table II are reported the basic agent used during the oxi-coprecipitation process. 
Table I. \% Ba coprecipitated in the oxiprecipitation process.

\begin{tabular}{|c|c|c|c|}
\hline $\mathrm{pH}$ & $20^{\circ} \mathrm{C}$ & $45^{\circ} \mathrm{C}$ & $70^{\circ} \mathrm{C}$ \\
\hline 10 & 30,2 & 23,9 & 7,4 \\
\hline 11 & 91,8 & 28,8 & 33 \\
\hline 12 & 36,8 & 89,9 & 88 \\
\hline 13 & 70,8 & 97,7 & 98,8 \\
\hline
\end{tabular}

Table II. Volume of $\mathrm{NaOH}$, in $\mathrm{ml}$, needed for the oxicoprecipitation process

\begin{tabular}{|c|c|c|c|}
\hline $\mathrm{pH}$ & $20^{\circ} \mathrm{C}$ & $45^{\circ} \mathrm{C}$ & $70^{\circ} \mathrm{C}$ \\
\hline 10 & 163 & 170 & 171 \\
\hline 11 & 188 & 180 & 181 \\
\hline 12 & 176 & 185 & 237 \\
\hline 13 & 183 & 507 & 700 \\
\hline
\end{tabular}

In the qualitative analysis, made by $\mathrm{XRD}$, up to $\mathrm{pH} 12$ there is a crystalline phase of $\mathrm{BaCO}_{3}$. That involves a different mechanism of coprecipitation. In all cases $\mathrm{NaCl}$ is present and the ferric phases are $\alpha-\mathrm{FeOOH}, \mathrm{Fe}_{3} \mathrm{O}_{4}$ alone or in a mixture [1]. The coprecipitation mechanism is a complex phenomena where superficial adsorption, occlusion and inclusion are present. The inclusion phenomena could be produced with or without removing iron to the dissolution. If $\mathrm{Ba}$ is inside the clystal structure it cannot react and cannot originate a crystal structure. If $\mathrm{Ba}$ is in the surface, it can react and forns a crystal structure. So, in this way, at low $\mathrm{pH}$, above 12 , the inclusion and occlusion phenomena are present and the adsorption phenomenon has no significance. Up to $\mathrm{pH} 12$ the adsorption phenomenon has significance. The substitution effect, removing iron to the solution has more signiticance at high temperature.

\subsection{Ba-hexaferrite formation.}

Ba-hexaferrite formation was processed at $900^{\circ} \mathrm{C}$ during 3 hours. The qualitative and quantitative analyses were done by XRD and the magnetic properties were obtained from their hysteresis loops. Table III shows the obtained results.

Table III. Qualitative and quantitative analysis and magnetic properties of obtained Ba-hexaferrites.

\begin{tabular}{|c|c|c|c|c|c|c|c|c|c|c|c|c|}
\hline $\begin{array}{c}\mathrm{T}\left({ }^{\circ} \mathrm{C}\right) \\
\mathrm{pH}\end{array}$ & $\begin{array}{l}20 \\
10\end{array}$ & $\begin{array}{l}20 \\
11\end{array}$ & $\begin{array}{l}20 \\
12\end{array}$ & $\begin{array}{l}20 \\
13 \\
\end{array}$ & $\begin{array}{l}45 \\
10\end{array}$ & $\begin{array}{l}45 \\
11\end{array}$ & $\begin{array}{l}45 \\
12 \\
\end{array}$ & $\begin{array}{l}45 \\
13 \\
\end{array}$ & $\begin{array}{l}70 \\
10\end{array}$ & $\begin{array}{l}70 \\
11 \\
\end{array}$ & $\begin{array}{l}70 \\
12 \\
\end{array}$ & $\begin{array}{l}70 \\
13\end{array}$ \\
\hline$\% \mathrm{BaFe}_{12} \mathrm{O}_{19}$ & $--\cdot$ & 91.7 & 5,2 & 66,0 & $-\cdots$ & 28.7 & 39,2 & --- & $\cdots$ & 66,8 & 81,1 & $\cdots$ \\
\hline $\mathrm{M}_{8}(\mathrm{emu} / \mathrm{g})$ & 3,3 & 49,2 & 10,1 & 25,4 & 6,9 & 16.0 & 17,1 & 6,7 & 3,8 & 25,5 & 35,4 & 0,6 \\
\hline $\mathrm{M}_{\tau}(\mathrm{emu} / \mathrm{g})$ & 0,2 & 28,5 & 0,6 & 15,4 & 2,2 & 7,1 & 10,0 & 2,9 & 0,4 & 15,0 & 22,3 & 0,01 \\
\hline$H_{c}(k A / m)$ & 31 & 420 & 26,0 & 358 & 101 & 154 & 353 & 222 & 30 & 326 & 375 & 26 \\
\hline
\end{tabular}

At $20^{\circ} \mathrm{C}$ and $\mathrm{pH} 11$ the liquor floculation promotes the adsolption process and the coprecipitation and the magnetic properties are abnormally high in relation to the others. In all cases $\mathrm{M}_{s}$ and $\mathrm{M}_{\mathrm{r}}$ are higher when the anount of $\mathrm{Ba}^{2+}$ is higher in the precipitate except at 45 and $70^{\circ} \mathrm{C}$ and $\mathrm{pH} 13$ where the magnetic properties are very low. The reason of that is the great amount of $\mathrm{NaCl}$ present in the powder.

\subsection{Effect of $\mathrm{NaCl}$.}

Some known amounts of $\mathrm{NaCl}$ were added in order to study the effect of $\mathrm{NaCl}$ in the precursor powder [2-3]. In these samples there are two kinds of $\mathrm{NaCl}$; the first one in the ferrous matrix generated by the precipitation process and the former $\mathrm{NaCl}$ added later. The results show that this known amount of $\mathrm{NaCl}$ did not affect the reaction extension neither the magnetic properties. We can conclude that $\mathrm{NaCl}$ minimizes the reaction temperature due to the defects promoted in the ferrous matrix and not as flux phase. A great amount of $\mathrm{NaCl}$ decreases the magnetic properties promoting the formation of intermediate phases.

\section{References}

[1] Misawa T., Hashimoto K. and Shimodaira S. Comosion Science 14 (1974) 131-149.

[2] Date S.K., Deshpande C.E., Kulkarni S.D. and Shrotri I.J. Proceedings ICI-5. (1989). 55-60

[3] Chang C.W., Tzeng M.S. and Wang S.J. Joumal of Matcrials Science I etters 9 (1990). 832-835. 